\title{
Selected risk factors of vascular access complications in patients treated at an intensive care unit
}

\section{Wybrane czynniki ryzyka wystąienia powikłań dostępów naczyniowych u chorych leczonych na oddziale intensywnej terapii}

\author{
Anna Michalik ${ }^{1}$, Agnieszka Gniadek² \\ ${ }^{1}$ Department of Nursing, Faculty of Health Sciences, University of Bielsko-Biala, Bielsko-Biala, Poland \\ Head of the Department: Prof. ATH Rafał Bobiński MD, PhD \\ ${ }^{2}$ Department of Nursing Management and Epidemiology Nursing, Faculty of Health Sciences, Jagiellonian University Medical College, \\ Krakow, Poland \\ Head of the Department: Prof. Tomasz Brzostek PhD
}

Key words: risk factors, complications, intensive care unit, intravascular access.

Słowa kluczowe: czynniki ryzyka, powikłania, oddział intensywnej terapii, dostęp śródnaczyniowy.

\begin{abstract}
Introduction: Vascular catheters constitute an indispensable element of the diagnostic-therapeutic procedure in critically ill patients. However, their insertion and maintenance is associated with the risk of occurrence of life-threatening complications. Aim of the research: To become familiar with selected risk factors of vascular access complications in patients treated at an intensive care unit.

Material and methods: Retrospective studies were carried out at an 11-bed multi-profile Intensive Care Unit in the South of Poland. The studies included using individual and collective medical documentation, the TISS-28 scale, as well as the SOFA and APACHE II classifying scales. The statistical analysis was performed using Statistica 10 PL software. The statistical inference was carried out with a $\alpha=0.05$ significance level.

Results and conclusions: Among 1742 inserted vascular accesses, complications occurred in 411 cases. The most frequent cause of decannulation was a suspected infection, an obstruction of the cannula, and the accidental removal of the cannula. The frequency of complications among peripheral venous accesses significantly differed from the mean frequency of complications for all types of intravascular accesses. The number of complications during application of vascular accesses was significantly linearly influenced by the number of accesses, the frequency of manipulations during care activities performed in relation to the cannulas, the number of days a patient stayed in the anaesthesiology and intensive care unit, and in the case of central, dialysis, and arterial catheters also the time of maintaining them. The decompensation of chronic respiratory failure, the duration of the stay at the anaesthesiology and intensive care unit, and the duration of hospitalisation correlated positively with the occurrence of complications, and the mean number of undertaken interventions in the TISS-28 scale correlated negatively.
\end{abstract}

\section{Streszczenie}

Wprowadzenie: Cewniki naczyniowe stanowią niezbędny element postępowania diagnostyczno-terapeutycznego u pacjentów krytycznie chorych. Jednak ich wprowadzenie i utrzymanie niesie ze sobą ryzyko wystąpienia groźnych dla życia powikłań. Cel pracy: Poznanie wybranych czynników ryzyka wystąpienia powikłań dostępów naczyniowych u chorych leczonych na oddziale intensywnej terapii.

Materiał i metody: Badania o charakterze retrospektywnym przeprowadzono na 11-łóżkowym wieloprofilowym oddziale intensywnej terapii na południu Polski. Do badań wykorzystano dokumentację medyczną indywidualną i zbiorczą, skalę TISS-28 oraz skale klasyfikujące SOFA i APACHE II. Analizę statystyczną wykonano przy użyciu programu Statistica 10 PL. Wnioskowanie statystyczne przeprowadzono przy poziomie istotności $\alpha=0,05$.

Wyniki i wnioski: Na 1742 założone dostępy naczyniowe powikłania wystąpiły w 411 przypadkach. Najczęstszą przyczyną dekaniulacji było podejrzenie infekcji, niedrożność kaniuli oraz jej przypadkowe usunięcie. Częstość występowania powikłań wśród dostępów żylnych obwodowych różniła się istotnie od średniej częstości powikłań dla wszystkich typów dostępów śródnaczyniowych. Na liczbę powikłań w trakcie stosowania dostępów naczyniowych istotny liniowy wpływ miały liczba dostępów, częstość manipulacji w trakcie opieki nad kaniulami, liczba dni pobytu pacjenta na oddziale anestezjologii i intensywnej terapii, a w przypadku cewników centralnych, dializacyjnych i tętniczych - także czas ich utrzymania. Z występowaniem powikłań dodatnio korelowały dekompensacja przewlekłej niewydolności oddechowej, czas pobytu na oddziale anestezjologii i intensywnej terapii, czas hospitalizacji, a ujemnie średnia liczba podjętych interwencji w skali TISS-28. 


\section{Introduction}

The functioning of intensive care units (ICUs) has contributed to the increasing survival chances of patients who are in a life-threatening condition. This, however, would not be possible without reliable and permanent intravascular access. In Poland there are no exact data indicating the frequency of application of intravascular catheters, whereas in the USA there are data, according to which the annual consumption of cannulas by ICUs amounts to 150 million [1-3]. The majority of patients in a life-threatening condition require access to large venous vessels; this results from the specificity of the applied diagnostics and therapy. However, the insertion and maintenance of an intravascular access in situ is not a procedure that is free of complications - the frequency of necessity for preterm removal of the vascular cannula related to the occurrence of an adverse event is estimated to be $20-50 \%$ [4-6]. The occurrence of complications results in the elongation of hospitalisation, increased cost of conducting the therapy, and what is more important - increased patient morbidity and mortality $[7,8]$. Therefore, the selection of the intravascular cannula should be thoughtful, and it should depend on the needs of the patient, on the foreseen duration of maintaining the catheter in the vessel, on the indications for inserting it, and on the skills of the operator. This is associated with certain behaviour characteristics of the patient, his/her environmental exposure, or inborn features related to the increased likelihood of occurrence of an adverse effect from use of the catheter - specific elements defined as risk factors $[9,10]$.

\section{Aim of the research}

The aim of the paper was the assessment of selected risk factors of the occurrence of vascular access complications in patients treated at an anaesthesiology and intensive care unit.

\section{Material and methods}

The studies were carried out at an 11-bed multiprofile ICU of a Municipal Hospital in the South of Poland in the period from January 2013 to March 2015. The persons included in the studies were those who underwent the procedure of gaining central vascular, peripheral arterial, and venous vascular access (597 patients).

The studies applied retrospective analysis using the analysis of individual and collective medical documentation, which included: the patients' medical history, the individual care card, the intensive treatment card, physicians' and nurses' reports, the procedure log book, and the results of diagnostic and microbiological examinations. The authors of the paper applied the SOFA, APACHE II, and the TISS-28 scale. Sequential Organ Failure Assessment (SOFA) was cre- ated to assess the degree of dysfunction of organs associated with sepsis, including: oxygenation degree, serum creatinine and bilirubin, number of platelets, mean arterial pressure, necessity to use catecholamines, and the patient's GCS score. The patient can receive from 1 to 4 points for each parameter, obtaining a final score in the range of 6-24 points [11].

Acute Physiology and Chronic Health Evaluation II (APACHE II) is a scale for assessing the severity of the condition in adults. The classification is based on the results of 12 routine measurements of vital signs and physiological parameters. Each of the evaluated variables is scored in the range of $0-4$ points, with a higher point limit in favour of a greater deviation from the norm. The patient can gain a maximum of 71 points. Obtaining 25 points is associated with a $50 \%$ risk of death, and a total of over 35 corresponds to a death risk of $80 \%$. The patient is evaluated within the first $24 \mathrm{~h}$ of admission to the ICU [12].

The Therapeutic Intervention Scoring System (TISS-28) classifies patients depending on the number of therapeutic interventions required. Each of the activities performed with the patient is classified to the appropriate point scale in the range 1 to 4 points, and the score is calculated once every $24 \mathrm{~h}$. It reflects the degree of involvement of nursing staff in the care of the patient. The maximum number of points that can be achieved on the TISS-28 scale is 78 [12].

Also, the studies applied our own questionnaire, used in order to collect the demographic data of the analysed group of patients, the date of admission to hospital, the date of admission to the ICU, the date of discharge from hospital/death, and the mode and type of admission to hospital. The data that were monitored also included the number and type of inserted vascular cannulas, the time of maintaining them, the number of manipulations, and the cause of decannulation.

The applicable procedures and standards of conduct as well as the medical equipment applied for the cannulation of vessels did not change during the gathering of the research material.

The Bioethical Committee (2012/12/14/3) and the Hospital Management provided consent to perform the studies.

\section{Statistical analysis}

The statistical analysis was performed using Statistica 10 PL software. The one-factor analysis of variance was used in the analysis of the homogeneity of the studied groups in reference to independent variables. In the case of non-homogeneous variance, the Mann-Whitney $U$ test was applied. The influence of many independent variables on a dependent variable was analysed using backward multiple regression analysis. The assessment of the interdependence of qualitative or quantitative variables of the ordinal scale type was performed ap- 
plying Pearson's chi-square test for independence $\left(\chi^{2}\right)$ or the chi-square test for independence $\left(\chi^{2}\right)$ using the maximum likelihood function. The statistical inference was carried out with a $\alpha=0.05$ significance level.

\section{Results}

\section{General characteristics of the studied group}

Nearly all of the patients were admitted to hospital in an emergency mode (96.5\%). The indications for admission to the ICU included acute respiratory failure $(51.6 \%)$, condition after sudden cardiac arrest $(17.4 \%)$, septic shock (16.1\%), decompensation of chronic circulatory failure (5.5\%), decompensation of chronic respiratory failure $(4.9 \%)$, hypovolaemic shock (3.5\%), polytrauma (0.8\%), and Guillain-Barre syndrome $(0.2 \%)$. Statistically significant differences were not found during the analysis of the reason for admission of the patients depending on the diagnosis and gender $\left(\chi^{2}=4.46, \mathrm{~d} f=7, p=0.7261\right)$.

Nearly one third $(30.6 \%)$ of the studied patients underwent a surgical procedure before admission to the ICU, mainly in the scope of the abdominal and cranial cavity.

The age of patients ranged between 13 and 96 years (mean \pm SD: $67 \pm 16.08$ years). Men constituted $60 \%$ of the hospitalised patients.

The mean duration of the patients' stay in the unit was $6.08 \pm 6.25$ days, and the mean duration of hospitalisation was $16.87 \pm 15.72$ days. The assessment of the patients' condition performed using classifying scales demonstrated that in the SOFA scale the patients obtained $8.19 \pm 3.44$ points and in the APACHE II scale $27.26 \pm 9.67$ points. During the stay at the ICU, the hospitalised patients obtained $233.55 \pm 232.61$ points in the TISS-28 scale, whereas the mean number of points in the TISS-28 scale during one day $(24 \mathrm{~h})$ of a patient's stay in the unit (mean TISS-28) was $32.58 \pm 7.50$ (Table 1).

\section{Vascular accesses inserted in the ICU patients}

The frequency of utilising the central vascular line in the analysed period was $82.4 \%$, and the frequency of utilising the peripheral vascular line was $97.3 \%$. The 597 studied patients underwent insertion of a total of 1742 intravascular accesses. The number of implanted vascular cannulas differed depending on the patient and on the type of intravascular access. The duration of maintaining vascular accesses differed depending on the type of the applied cannula (Table 2).

\section{Causes of the removal of vascular accesses among ICU patients}

The completion of intensive treatment (36.3\%) was the most frequently occurring cause of decannulation, and the second was the patient's death (31.1\%). Among 1742 inserted vascular accesses, complications occurred in 411 cases. Among complications the most frequently occurring event were infectious complications (34\%), obstruction of the cannula (24.2\%), and accidental removal of the cannula (18.3\%). Most frequently complications occurred among peripheral venous accesses $(36.2 \%)$, which was significantly more frequent in reference to the mean frequency of complications for the remaining types of intravascular access (Table 3).

\section{The duration of maintaining particular vascular accesses vs. the complications}

In the group of patients who experienced complications the CVC was maintained in the vessel for $9.06 \pm 7.22$ days, and in the group without complications for $7.953 \pm 7.05$ days. The Mann-Whitney $U$ test demonstrated a statistically non-significant difference between the duration of maintaining the central catheter and the occurrence of complications ( $p=0.0565)$. However, the statistical analysis of the influence of the duration of maintaining the cannula in the vessel

Table 1. The general characteristics of the studied group of patients hospitalised at the ICU elaborated with the use of classifying scales

\begin{tabular}{|lccccccccc|}
\hline Independent variables & $\boldsymbol{N}$ & Median & Mean & Min. & Max. & SD & Skewness & Kurtosis \\
Age [years] & 596 & 64.70 & 67 & 13 & 96 & 16.08 & -0.71 & 0.11 \\
Duration of stay at the ICU [days] & 597 & 6.08 & 4 & 1 & 44 & 6.25 & 2.47 & 8.54 \\
Duration of hospitalisation [days] & 597 & 16.87 & 13 & 1 & 101 & 15.72 & 1.81 & 4.12 \\
SOFA & 377 & 8.19 & 8 & 1 & 20 & 3.44 & 0.50 & 0.26 \\
APACHE II & 349 & 27.26 & 27 & 6 & 63 & 9.67 & 0.39 & -0.08 \\
TISS-28 & 597 & 233.55 & 163 & 13 & 1913 & 232.61 & 2.89 & 12.33 \\
TISS-28 mean & 597 & 32.58 & 32 & 4.33 & 66 & 7.50 & 0.13 & 2.01 \\
\hline
\end{tabular}

$N$ - the number of the studied patients, Min. - minimum, Max. - maximum, SD - standard deviation, ICU - Anaesthesiology and Intensive Care Unit, SOFA - Sepsis-related Organ Failure Assessment, APACHE II - Acute Physiology and Chronic Health Evaluation II, TISS-28 - Therapeutic Intervention Scoring System. 
Table 2. A juxtaposition of the duration of maintaining particular vascular accesses

\begin{tabular}{|c|c|c|c|c|c|c|c|c|c|c|}
\hline $\begin{array}{l}\text { Type } \\
\text { of catheter }\end{array}$ & $\begin{array}{l}\text { Number of inserted } \\
\text { accesses }\end{array}$ & $N$ & $\begin{array}{l}\text { Catheter- } \\
\text { days }\end{array}$ & Mean & Median & SD & Min. & Max. & Q25 & Q75 \\
\hline \multirow[t]{4}{*}{ CVC } & 1 & 440 & 3425 & 7.82 & 7 & 6.73 & 1 & 52 & 3 & 10 \\
\hline & 2 & 43 & 484 & 11.26 & 8 & 9.29 & 1 & 39 & 4 & 15 \\
\hline & 3 & 4 & 59 & 14.75 & 10 & 10.21 & 9 & 30 & 9 & 20.5 \\
\hline & In general & 487 & 3968 & 8.18 & & 7.09 & 1 & 52 & & \\
\hline \multirow[t]{3}{*}{$C D$} & 1 & 122 & 1136 & 9.39 & 7 & 8.51 & 1 & 41 & 3 & 12 \\
\hline & 2 & 7 & 77 & 11.00 & 10 & 7.75 & 4 & 27 & 6 & 13 \\
\hline & In general & 129 & 1213 & 9.48 & & 8.45 & 1 & 41 & & \\
\hline \multirow[t]{6}{*}{$A C$} & 1 & 551 & 3009 & 5.46 & 4 & 3.91 & 1 & 26 & 2 & 7 \\
\hline & 2 & 157 & 967 & 6.16 & 5 & 4.77 & 1 & 37 & 3 & 7 \\
\hline & 3 & 37 & 299 & 8.08 & 7 & 5.80 & 1 & 24 & 3 & 10 \\
\hline & 4 & 17 & 125 & 7.35 & 6 & 4.05 & 2 & 14 & 3 & 11 \\
\hline & 5 & 2 & 19 & 9.50 & 9.5 & 10.61 & 2 & 17 & 2 & 17 \\
\hline & In general & 764 & 4419 & 5.78 & & 4.27 & 1 & 37 & & \\
\hline \multirow[t]{6}{*}{ PVC } & 1 & 208 & 719 & 3.46 & 3 & 2.04 & 1 & 11 & 2 & 4 \\
\hline & 2 & 83 & 285 & 3.43 & 3 & 2.03 & 1 & 12 & 2 & 4 \\
\hline & 3 & 31 & 103 & 3.32 & 3 & 1.64 & 1 & 8 & 2 & 4 \\
\hline & 4 & 13 & 37 & 2.85 & 2 & 1.68 & 1 & 7 & 2 & 3 \\
\hline & 5 & 5 & 13 & 2.60 & 3 & 0.55 & 2 & 3 & 2 & 3 \\
\hline & In general & 340 & 1157 & 3.40 & & 1.98 & 1 & 12 & & \\
\hline
\end{tabular}

$N$ - number of valid ones, CVC - central venous catheter, CD - dialysis catheter, AC - arterial cannula, $P V C$ - peripheral venous catheter, SD - standard deviation, Min. - minimum, Max. - maximum, Q25 - first quartile, Q75 - third quartile.

Table 3. The frequency of complications depending on the type of applied intravascular cannula

\begin{tabular}{|c|c|c|c|c|c|c|}
\hline \multirow[t]{2}{*}{ Type of cannula } & \multirow{2}{*}{$\begin{array}{l}\text { Number } \\
\text { of accesses }\end{array}$} & \multicolumn{2}{|c|}{ Without complications } & \multicolumn{2}{|c|}{ Complications } & \multirow[t]{2}{*}{$P$-value } \\
\hline & & $N$ & $\%$ & $N$ & $\%$ & \\
\hline CVC & 487 & 387 & 79.5 & 100 & 20.5 & 0.1632 \\
\hline$C D$ & 129 & 106 & 81.4 & 23 & 18.6 & 0.2004 \\
\hline$A C$ & 764 & 599 & 78.7 & 165 & 21.3 & 0.2271 \\
\hline PVC & 340 & 217 & 63.8 & 123 & 36.2 & $<0.0001$ \\
\hline IABP & 6 & 6 & 100 & 0 & 0 & 0.1744 \\
\hline S-G & 11 & 11 & 100 & 0 & 0 & 0.0660 \\
\hline EL & 5 & 5 & 100 & 0 & 0 & 0.2145 \\
\hline In general & 1742 & 1331 & 76.5 & 411 & 23.5 & \\
\hline
\end{tabular}

$N$ - number of accesses, $p$ - statistical significance of differences, CVC - central venous catheter, $C D$ - dialysis catheter, $A C$ - arterial cannula, $P V C$ - peripheral venous catheter, IABP - balloon for intra-aortic counterpulsation, S-G - Swan-Ganz catheter, EL - endocavitary electrode.

demonstrated that the frequency of complications significantly depended on the duration of maintaining the catheter in the vessel $(p=0.0436)$.

In the group of patients with complications the dialysis catheter remained in the vessel for 11.50 \pm 6.65 days, and in the group of persons in whom complications did not occur for $9.01 \pm 8.78$ days, which was a statistically significant difference ( $p=0.0137)$. Moreover, it was found that the frequency of complications significantly depended on the duration of maintaining the dialysis catheter in the vessel $(p=0.0427)$. 


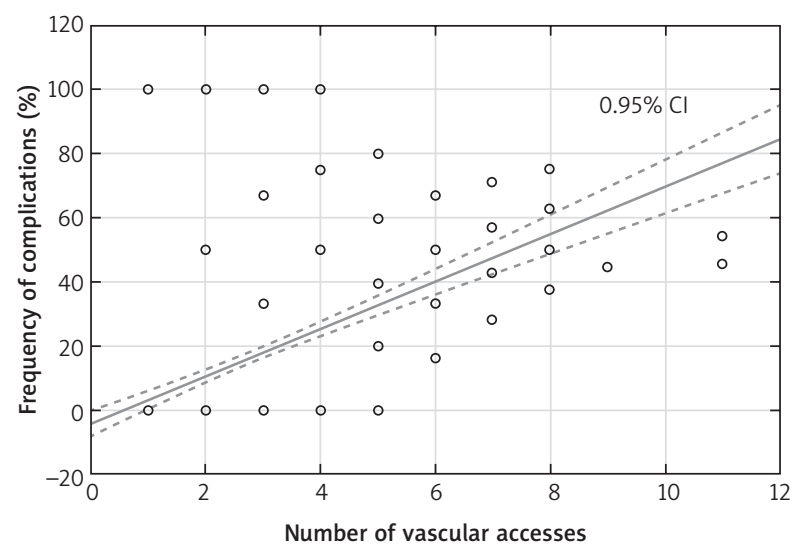

Figure 1. The dispersion of the frequency of complications depending on the number of vascular accesses

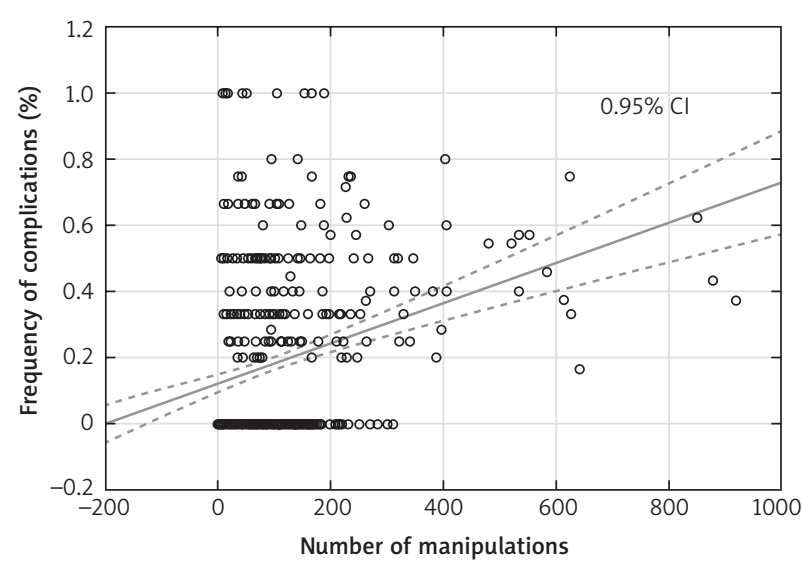

Figure 2. The dispersion of the variable "Number of manipulations" in reference to the frequency of vascular access complications

The mean duration of maintaining the intra-arterial cannula in the group of patients who experienced a complication was $6.387 \pm 5.24$ days, whereas in the group without complications it was $5.621 \pm 3.95$ days. A statistically significant difference was not found between the mean duration of maintaining the arterial cannula and the occurrence of complications $(p=0.4787)$. However, it was found that the frequency of complications significantly depended on the duration of maintaining the cannula in the artery $(p=0.0016)$.

Among peripheral intravenous accesses the duration of maintaining the cannula in the vessel in the group of persons with complications was $3.15 \pm 1.78$ days, whereas in the group without complications it was $3.55 \pm 2.07$ days. The analysis performed applying the Mann-Whitney $U$ test with the continuity correction demonstrated a statistically significant difference $(p=0.0452)$. However, the frequency of occurrence of complications did not significantly depend on the duration of maintaining the cannula ( $p=0.1503)$.
The number of applied vascular accesses vs. the complications

The studied patients were differentiated in terms of the number of inserted vascular accesses during the stay at the ICU. The number of the cannulas inserted in one patient ranged from 1 to 11 . It was found that the number of complications increased along with the increase in the number of inserted accesses. The implantation of six or more catheters in 1 patient during therapy was associated with a 100\% likelihood of complications. The statistical analysis demonstrated that the number of complications increased linearly together with the number of inserted vascular accesses $(p<0.0001)$ (Figure 1).

\section{The number of manipulations vs. vascular access complications}

The number of manipulations in the group of persons with complications was $150 \pm 155.89$, and in the group of persons without complications it was $71 \pm 62.09$. A statistically significant difference was found between the number of manipulations and the occurrence of complications ( $p<0.0001)$. The analysis demonstrated that the frequency of vascular access complications increased linearly together with the number of manipulations (Figure 2). A lack of a significant difference between the mean number of manipulations and the occurrence of complications ( $p=0.2053)$ was found during the analysis of the mean number of manipulations related to the vascular access per day $(24 \mathrm{~h})$. In the group of patients with complications the mean number of manipulations per day $(24 \mathrm{~h}$ ) was $13.58 \pm 6.22$, and in the group without complications it was nearly the same, i.e. $13 \pm 8.28$.

The number of undertaken interventions in the TISS-28 scale vs. vascular access complications

In the group of patients who experienced intravascular access complications the mean score in the TISS-28 scale was $349.26 \pm 308.84$, in the range from 13 to 1913 points. In the group of patients without complications the mean score was $162.23 \pm 123.12$, in the range from 18 to 628 points. It was demonstrated that - significantly more frequently - the greater the number of interventions according to the TISS28 scale, the greater the number of complications $(p<0.0001)$ (Figure 3). Taking into consideration the mean number of points per day $(24 \mathrm{~h})$ obtained by the patients hospitalised at the ICU, a statistically significant difference was not found $(p=0.5190)$. The patients in whom there were complications in the TISS28 scale obtained $32.34 \pm 6.74$ points, in the range from 4.33 to 66 , whereas patients who did not experience complications obtained $32.75 \pm 7.93$ points, in the range from 2 to 60.50 points. 


\section{The duration of hospitalisation at the ICU vs. vascular access complications}

The mean duration of stay in the ICU in the group of patients who experienced complications was 10.39 \pm 8.10 days and in the group of patients without complications the duration was shorter, at $4.93 \pm 3.56$ days. The statistical analysis demonstrated that the duration of stay had a significant influence on the occurrence of complications in the studied group $(p<0.0001)$. The longer the patient stayed in the ICU, the higher the number of vascular access complications.

The analysis of the influence of selected variables on the occurrence of vascular access complications

Logistic regression analysis was applied in order to assess which of the selected factors had the greatest influence on the occurrence of vascular access complications. It was found that the only statistically significant factors having an influence on the occurrence of vascular access complications in the studied group were the decompensation of chronic respiratory failure, the duration of the stay in the ICU, the duration of hospitalisation, and the mean number of undertaken interventions in the TISS-28 scale; for these interventions the determination coefficient was $R^{2}=0.18$ with a $p<0.001$ significance level. The demonstrated correlation was positive with the decompensation of chronic respiratory failure, the duration of stay at the ICU, and with the duration of hospitalisation, and the correlation was negative with the mean number of undertaken interventions in the TISS-28 scale (Figure 4).

\section{Discussion}

The type of applied cannula results from the planned diagnostic-therapeutic activities, the patient's condition, the preferences of the operator, the guidelines for conducting the therapy related to critically ill patients, and from the unit's internal procedures [13]. Studies carried out by Ricard et al. in the group of critically ill patients of three French ICUs demonstrated that the preferred access is central access, due to the lower percentage of complications [14]. The results of our own studies demonstrated that the highest number of adverse events occurred among peripheral venous accesses, which confirms that in reference to critically ill patients the preferred vascular access is the central access. This may be related to the intensive medication therapy and fluid therapy applied in the first days of the ICU stay. Moreover, it seems probable that in reference to central accesses, recommendations for aseptic and antiseptic conduct are introduced and respected to a higher degree; whereas, in the opinion of the medical staff, peripheral accesses do not seem to be a risk factor for serious threats.

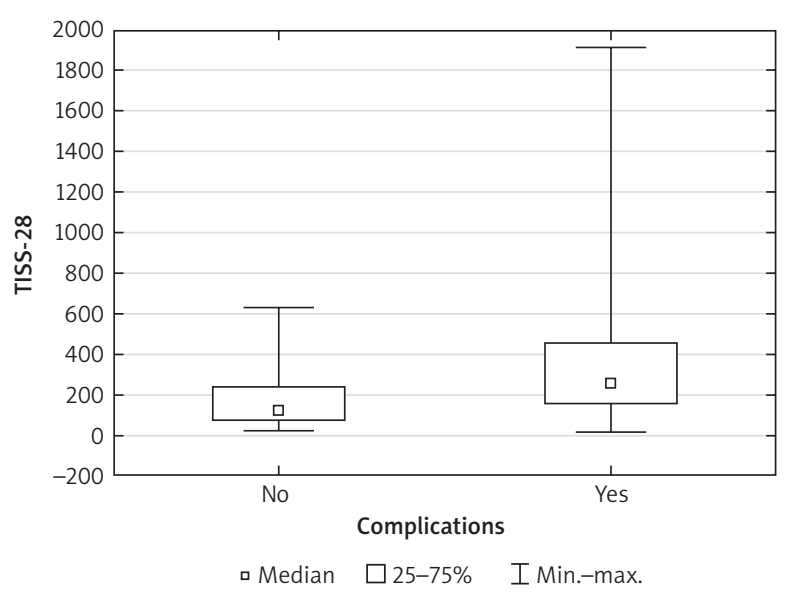

Figure 3. The occurrence of complications depending on the TISS-28 score

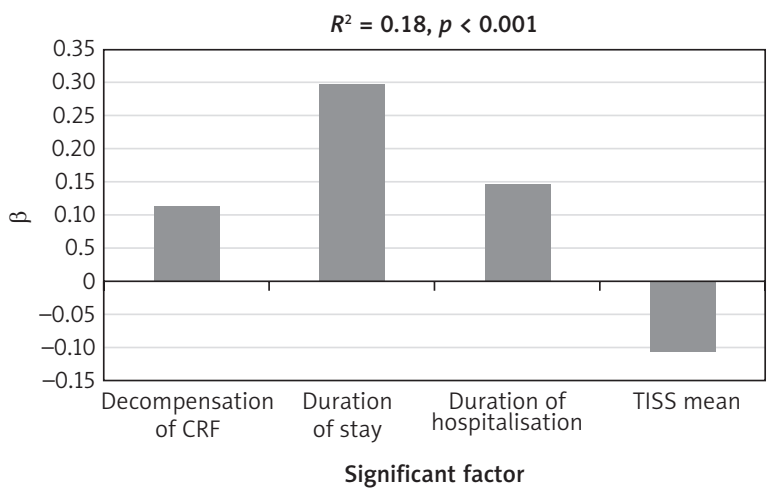

Figure 4. Significant risk factors of vascular access complications

$\beta$-variable regression coefficient, CRF-chronic respiratory failure, Duration of stay - the duration of the stay in the ICU, TISS meanTISS-28 mean score.

The duration of maintaining the central vascular line is one of the most important risk factors for the occurrence of a catheter-related infection [15, 16]. The removal of the cannula in the moment when its maintained is not clinically justified, which is an important element of preventive actions. However, in $8.3 \%$ of cases the medical staff are not able to define the indications for maintaining it, which proves the lack of daily verification of the necessity to maintain the catheter in situ [17]. In our own studies the mean duration of maintaining the central catheter in the group of patients who experienced complications was 9.06 days, and in the group without complications it was 7.95 days, which constituted a difference that was not statistically significant. In accordance with recommendations, the necessity to maintain the catheter in the vessel was verified on a daily basis.

Studies carried out by Nakae et al. among critically ill patients with an inserted temporary haemodialysis access in the years 2004-2008 did not demonstrate 
a significant difference in the occurrence of infectious complications in the group of patients who had a vascular catheter inserted for 1 and 2 weeks [18]. In our own studies it was noticed that the frequency of the complications significantly depended on the duration of maintaining the dialysis catheter in the vessel.

In our own studies, among intraarterial accesses, it was demonstrated that the frequency of complications significantly depended on the time of maintaining the cannula in situ. According to some publications, the longer the duration of cannulation, the higher the risk of infectious complications [19-21], but not all publications concur [22]. The CDC does not recommend the routine replacement of cannulas in reference to the prevention of infectious complications [23]. In accordance with those guidelines, routine replacement of arterial cannulas was not performed in the studied group.

In the group of peripheral intravenous cannulas in our own studies the duration of maintaining the Venflon in the group of patients with complications was (mean) 3.15 days and in the group without complications it was 3.55 days. It was found, however, that the frequency of occurrence of complications did not significantly depend on the duration of maintaining the cannula $(p>0.05)$. The first days of cannulation at the ICU are related to intensive pharmacotherapy and fluid therapy, which is frequently performed using fluids of an increased $\mathrm{pH}$. This may be the why the percentage of complications was highest in the first days of using the Venflon. The issue that is of crucial significance for the functional assessment of the peripheral catheter is the notion of the time during which the intravascular cannula maintains its safe function. A peripheral venous access frequently requires replacement during the course of intravenous therapy. Reports indicate that the percentage of cases of access replacement due to its disrupted functioning amounts to 33-69\% (accidental removal, inflammation of the venous vessel, obstruction, leak, or infection in the place of the puncture) [24, 25]. Until recently, based on observational data, the duration of maintaining the catheter in the vessel was limited to 72-96 h. Recently, the permissible duration of maintaining the cannula in the vessel has changed towards the possibility of maintaining the cannula in the vessel until the moment when the reinsertion is "clinically advised" - this results from the latest observational and prospective randomised, controlled trials [24, 26, 27].

The studied group of ICU patients was differentiated in terms of the number of inserted vascular accesses. The implantation of six or more catheters in one patient was associated with 100\% likelihood of complications. Moreover, the analysis of our own studies demonstrated that the frequency of complications increased linearly along with the number of inserted vascular accesses. This may be associated with greater exposure to mechanical complications resulting from earlier cannulations, the disruption of the continuity of skin layers, a higher number of manipulations, and the resulting higher risk of contamination of the inserted vascular catheters. The necessity to maintain several accesses also resulted from the originally more severe condition of the patient, which could influence the occurrence of adverse events related to the insertion and maintenance of intravascular accesses. The results of our own studies are compliant with the reports of other authors, which indicate that earlier cannulations and maintaining several vascular accesses simultaneously increase the risk of the occurrence of complications [6].

Conducting infusion therapy, the administration of medications, preparing sets for continuous haemodynamic monitoring, or taking samples for diagnostic examinations belong to the basic elements of a nurse's work with a critically ill patient. The safety of the preparation as well as of the procedure during the administration of infusion therapy is of crucial significance in the prophylaxis of adverse events. Every performed activity concerning the vascular access should be carried out after performing procedures ensuring hand hygiene. The decontamination of hands is more frequently performed in ICUs; however, it is not performed at the expected level. It is estimated that, on average, the number of necessary special hygienic activities related to the procedure of hand hygiene performed by medical staff during an hour is 82 [28]. The number of manipulations related to the vascular access should be limited to the necessary minimum. This is because every manipulation may be related with the risk of complications, both mechanical and infectious. A higher number of manipulations generates more chances for the contamination of the cannula $[29,30]$. This has been confirmed by our own studies, in which a statistically significant difference was demonstrated between the number of manipulations and the occurrence of complications $(p<0.0001)$. Moreover, the frequency of vascular access complications increased linearly together with the number of manipulations. The analysis of the mean number of manipulations related to the vascular access per day $(24 \mathrm{~h})$ demonstrated a lack of significant difference between the mean number of manipulations and the occurrence of vascular access complications ( $p>0.05)$, which may be explained by the correct behaviour during the handling of vascular lines.

Persons who obtain $20-39$ points in the TISS-28 scale require intensive treatment in the conditions of an ICU. In many countries the TISS-28 scale has been adopted as the "gold standard", allowing for management of human resources, especially nursing staff [31]. Studies carried out by Hariharan et al. at ICUs in three public and two private hospitals in Trinidad demonstrated that nurses scored (mean) 26.2 points [32]. In our own studies the patients hospitalised at the ICU obtained (mean) 32.58 points in the TISS-28 scale. Additionally, the high number of undertaken interventions in the TISS-28 scale significantly influ- 
enced the occurrence of vessel cannulation complications $(p<0.0001)$ in the studied group; this may be explained by the originally severe condition of the patient, which required invasive mechanical ventilation, the administration of pressor amines (in order to support the circulatory system), renal replacement therapy, applying parenteral nutrition, which was also associated with the necessity to insert several vascular accesses simultaneously, and with a higher number of manipulations. The analysis of the mean number of points per day $(24 \mathrm{~h})$ did not demonstrate a statistically significant difference $(p>0.05)$, which may prove the correct behaviours related to the cannulation and to the care procedures performed in reference to intravascular catheters.

Due to its specificity, the presence of critically ill patients requiring particular diagnostic-therapeutic procedures and due to a specific bacterial microflora, the ICU is not an environment that is optimum for the patient. Therefore, the present study assessed whether the number of days spent in the ICU was related to the occurrence of vessel cannulation complications. The statistical analysis of our own research demonstrated that the duration of stay had a significant influence on the occurrence of complications $(p<0.0001)$. It was demonstrated that the increase in the number of days of stay was accompanied by a linear increase in the percentage of complications. What is more, the elongation of the duration of the stay was accompanied by an increase in the number of complications $(p<0.001)$. This could have resulted from the longer patient exposure to the colonisation with the hospital bacterial microflora, the higher number of interventions, the more severe original condition of the patient, and thus the necessity to obtain several vascular accesses and their replacement several times during hospitalisation. Additionally, a longer stay at the ICU was associated with the necessity to implement numerous invasive medical procedures. It is difficult to find researcher reports that refer to the relationship between the duration of stay at the ICU and the occurrence of vascular access complications. The available publications concentrate on infectious complications of vascular accesses and on the duration of hospitalisation before the implantation of an intravascular cannula, as well as on the influence of the occurrence of infectious complications of vascular accesses on the lengthened duration of hospitalisation at the ICU. This is confirmed by studies conducted by Zingg et al., which demonstrated that in the group of patients with CLA-BSI the duration of hospitalisation and of the stay at the ICU was statistically significantly higher than in the group of patients without infectious complications related to vascular accesses [33].

The conducted studies draw attention to the risk factors of vascular access complications in the group of critically ill patients treated at the ICU. It seems justified to continue these studies with the division into particular types of vascular accesses and the differentiation of specific critical points for particular intravascular cannulas with the division into mechanical and infectious complications.

\section{Conclusions}

The application of peripheral venous vascular accesses was burdened with significantly more frequent occurrence of complications in comparison to other intravascular accesses. The elements that had a significant linear influence on the number of complications during the application of vascular accesses were the number of accesses, the frequency of manipulations during care activities related to the cannulas, the number of days of a patient's stay at the ICU, and in the case of central, dialysis, and arterial catheters also the duration of maintaining them. The element that had a significant influence on the occurrence of vascular access complications assessed using the TISS-28 scale was the high number of undertaken interventions during the general duration of maintaining the vascular accesses in a patient, but not the mean number of undertaken interventions per day $(24 \mathrm{~h})$ during the maintenance of the intravascular cannula. The severity of the health status of patients assessed using the SOFA and APACHE II scales did not influence the frequencies of occurrence of complications related to the application of vascular accesses. It is not possible to clearly determine which risk factors most strongly influence the occurrence of vascular access complications, because the influence of a given risk factor changes depending on the type of the access, and it is necessary to consider the factors separately. In order to prevent the occurrence of complications, there is a necessity for a holistic approach to the patient, responsibility in the performance of diagnostic-therapeutic procedures, collaboration between all of the members of the therapeutic team in the care related to the vascular access in reference to respecting guidelines and recommendations, and also the necessity to perform scientific research.

\section{Conflict of interest}

The authors declare no conflict of interest.

\section{References}

1. Mermel LA, Farr BM, Sherertz RJ, Raad II, O'Grady N, Harris JS, Craven DE. Guidelines for the management of intravascular catheter-related infections. Clin Infect Dis 2001; 32: 1249-1272.

2. Deduńska K, Dyk D. Prevention of bloodstream infections associated with the maintenance of central vascular catheters - literature review. Anest Ratow 2015; 9: 420-426.

3. Collignon PJ. Intravascular catheter associated sepsis: a common problem. The Australian Study on Intravascular Catheter Associated Sepsis. Med J Aust 1994; 161: 374-378.

4. Webster J, Clarke S, Paterson D, Hutton A, van Dyk S, Gale C, Hopkins T. Routine care of peripheral intravenous catheters versus clinically indicated replacement: randomised controlled trial. BMJ 2008; 337: a399. 
5. Lim MY, Al-Kali A, Ashrani AA, Begna KH, Elliott MA, Hogan WJ, Hook CC, Kaufmann SH, Letendre L, Litzow MR, Patnaik MS, Pardanani A, Tefferi A, Wolanskyj AP, Grill DE, Pruthi RK. Comparison of complication rates of Hickman catheters versus peripherally inserted central catheters in patients with acute myeloid leukemia undergoing induction chemotherapy. Leuk Lymphoma 2013; 54: 1263-1267.

6. Napalkov P, Felici DM, Chu LK, Jacobs Jr, Begelman SM. Incidence of catheter-related complications in patients with central venous or hemodialysis catheters: a health care claims database analysis. BMC Cardiovasc Disord 2013; 13: 86.

7. Jha M, Sunil Kumar V, Bokil S, Galante D. Complications of central venous catheter cannulation in tertiary care hospital ICU, a 2 years retrospective, observational study. Ped Anesth Crit Care J 2013; 1: 87-92.

8. Kaur R, Mathai AS, Abraham J. Mechanical and infectious complications of central venous catheterizations in a tertiary-level intensive care unit in northern India. Indian J Anaesth 2012; 56: 376-381.

9. Polderman $\mathrm{KH}$, Girbes AJ. Central venous catheter use. Part I: mechanical complications. Intensive Care Med 2002; 28: 1-17.

10. Ratajewski W, Małyszko J. Temporary vascular access in hemodialysed patients. Nefrol Dial Pol 2013; 17: 76-82.

11. Bouch C, Thompson JP. Severity scoring system in the critically ill. Continuing Education in Anaesthesia, Critical Care Pain 2008; 8: 181-185.

12. Miranda DR. The Therapeutic Intervention Scoring System: one single tool for the evaluation of workload the work process and management? Intensive Care Med 1997; 23: 615-617.

13. Grove J, Pevec W. Venous thrombosis related to peripherally inserted central catheters. J Vasc Interv Radiol 2000; 11: 837-840.

14. Ricard JD, Salomon L, Boyer A, Thiery G, Meybeck A, Roy C, Pasquet B, Le Mière E, Dreyfuss D. Central or peripheral catheters for initial venous access of ICU patients: a randomized controlled trial. Crit Care Med 2013; 41: 2108-2115.

15. Pronovost $\mathrm{P}$, Needham $\mathrm{P}$, Berenholts S, Sinopoli D, Chu H, Cosgrove S, Sexton B, Hyzy R, Welsh R, Roth G, Bander J, Kepros J, Goeschel C. An intervention to decrease catheter-related bloodstream infections in the ICU. N Engl J Med 2006; 355: 2725-2732.

16. Souweine B, Traore O, Aublet-Cuvelier B, Badrikian L, Laurent B, Sirot J, Gazuy N, Laveran H, Deteix P. Dialysis and central venous catheter infections in critically ill patients: results of a prospective study. Crit Care Med 1999; 27: 2394-2398.

17. Zingg W, Sandoz L, Inan C, Cartier V, Clergue F, Pittet D, Walder B. Hospital-wide survey of the use of central venous catheters. J Hosp Infect 2011; 77: 304-308.

18. Nakae H, Igarashi T, Tajimi K. Catheter-related infections via temporary vascular access catheters: a randomized prospective study. Artif Organs 2010; 34: E72-E76.

19. Esteve F, Pujol M, Pérez XL, Ariza J, Gudiol F, Limon E, Verdaguer R, Manez R. Bacteremia related with arterial catheter in critically ill patients. J Infect 2011; 63: 139-143.

20. Scheer B, Perel A, Pfeiffer UJ. Clinical review: complications and risk factors of peripheral arterial catheters used for haemodynamic monitoring in anaesthesia and intensive care medicine. Crit Care 2002; 6: 199-204.
21. Koh DB, Gowardman JR, Rickard CM, Robertson IK, Brown A. Prospective study of peripheral arterial catheter infection and comparison with concurrently sited central venous catheters. Crit Care Med 2008; 36: 397-402.

22. Traoré O, Liotier J, Souweine B. Prospective study of arterial and central venous catheter colonization and of arterialand central venous catheter-related bacteremia in intensive care units. Crit Care Med 2005; 33: 1276-1280.

23. O'Grady NP, Alexander M, Burns LA, Dellinger EP, Garland J, Heard SO, Lipsett PA, Masur H, Mermel LA, Pearson ML, Raad II, Randolph A, Rupp ME, Saint S, Healthcare Infection Control Practices Advisory Committee (HICPAC). Summary of recommendations: Guidelines for the Prevention of Intravascular Catheter-related infections. Clin Infect Dis 2011; 52: 1087-1099.

24. Webster J, Osborne S, Rickard C, New K. Clinically-indicated replacement versus routine replacement of peripheral venous catheters. Cochrane Database Syst Rev 2010; 3 : CD007798.

25. Rickard CM, Webster J, Wallis MC, Marsh N, McGrail MR, French V, Foster L, Gallagher P, Gowardman JR, Zhang L, McClymont A, Whitby M. Routine versus clinically indicated replacement of peripheral intravenous catheters: a randomised controlled equivalence trial. Lancet 2012; 380: 1066-1074.

26. Bolton D. Improving peripheral cannulation practice at an NHS trust. Br J Nurs 2010; 19: 1346-1350.

27. Ho KH, Cheung DS. Guidelines on timing in replacing peripheral intravenous catheters. J Clin Nurs 2012; 21: 1499-1506.

28. Miętkiewicz S, Siczyńska B, Dyk D. Hand hygiene and reduction of hospital infections. Is it worthwhile to undertake activities aimed to improve hand hygiene? Probl Hig Epidemiol 2014; 95: 580-585.

29. Scales K. Arterial catheters: indications, insertion and use in critical care. Br J Nurs 2010; 19: 16-21.

30. Koh DB, Robertson IK, Watts M, Davies AN. A retrospective study to determine whether accessing frequency affects the incidence of microbial colonisation in peripheral arterial catheters. Anaesth Intensive Care 2010; 38: 678-684.

31. Wysokiński M, Ksykiewicz-Dorota A, Fidecki W. Scope of nursing care in polish intensive care units. Biomed Res Int 2013; 2013: 463153.

32. Hariharan S, Chen D, Merritt-Charles L, Bobb N, DeFreitas L, Esdelle-Thomas JMA, Charles D, Colley K, Renaud E. The utilities of the therapeutic intervention scoring system (TISS-28). Indian J Crit Care Med 2007; 11: 61-67.

33. Zingg W, Cartier V, Inan $C$, Touveneau S, Theriault $M$, Gayet-Ageron A, Clergue F, Pittet D, Walder B. Hospitalwide multidisciplinary, multimodal intervention programme to reduce central venous catheter-associated bloodstream infection. PLoS One 2014; 9: e93898.

\section{Address for correspondence:}

\section{Anna Michalik}

Department of Nursing

Faculty of Health Sciences

University of Bielsko-Biala

ul. Willowa 2, 43-309 Bielsko-Biała, Poland

Phone: +48338279403

E-mail: a.michalik@ath.bielsko.pl 